\title{
UNIVERSITY EDUCATION OF PEDAGOGUES MEETING DEMANDS OF SCHOOL PRACTICE
}

ABSTRACT. University education is met with new demands for different models of work which will more successfully prepare students for societal challenges, a higher quality of involvement in school practice, and a constant personal adaptability. The duty of university education is to meet the needs of society by constantly raising the level and quality of its curricula and thus influence the quality of candidate preparation which is needed for the work environment. However, the quality of education of future candidates should be monitored through the school practice; therefore, university teaching models need to rely on strengths and weakness observed in practice as well as on legislative guidelines which regulate the work of school pedagogues. The goal of this research is focused on the examination of attitudes of pedagogy specalists and pedagogy students, as well as on differences in opinion on the influence of initial education on the application of theoretical knowledge and the development of skills which are related to concrete tasks in school practice. The obtained results showed that there are statistically significant differences between opinions of students and pedagogues when it comes to certain items: participating in and making institution's annual work plan; preparing yearly and monthly pedagogue work plans; forming classes; monitoring of educational work; providing support for teachers in working with students who need additional support.

aleksandraa@ucfak.ni.ac.rs; daliborka.p76@gmail.com

This paper was submitted on August 14, 2017 and accepted for publication at the meeting of the Editorial Board held on September 19, 2017. 
KEYWORDS: university education, school, pedagogy students, school pedagogues, regulation book on the work program for learning specialists - pedagogues.

\section{INTRODUCTION}

Tertiary education curricula, meant for students who will work in schools, have a slower rhythm compared to the intensity of the change in demands of school reality; in addition, outcomes and competencies of graduates do not produce narrowly profiled experts who are ready for professional demands. Makulova, A. \& al. (2015, p. 183) state that

"Qualitatively new mission, the objectives and content of modern education in the new conditions is intended to be focused not just on the fundamental knowledge, but on the labor market, and on the formation of a practically oriented skills and competencies".

Multiple findings from different countries, point to a dissatisfaction with the traditional approaches in teacher education. Researchers also point to an incompatibility between students' knowledge and the competencies which are required for practical work in school. Apart from former theorists, like John Dewey (2001), who stressed action, the significance of experience, and practical work and practical experience as the source of knowledge, this idea has never stopped being the subject of many researchers in education. More than three decades ago (Lortie, 1975) pointed out that teachers learn best from experiences of teaching, introducing a term related to teacher education and work, "apprenticeships of observations". Modern authors Zeichner \& Tabachnick (1981) showed that many notions and educational conceptions, developed during preservice teacher education, were "washed out" during field experiences, signifying the strong influence of practice on their experience.

Lee Shulman $(1986,1987)$ remained famous for the notion of PCK-pedagogical content knowledge, by which he confirms the essential idea of teaching, and that is the duty of the teacher to connect real life and practice..." teachers need to see how ideas connect across fields and to everyday life". Even now, Shulman knowledge set is being developed, by numerous theorists and researchers. According to Shulman, programs which educate future teachers are in great measure responsible for the formation 
of teacher's attitude to teaching. Dichotomy of knowledge of new workers with practical tasks in school practice is a problem indicated by researchers from different countries. Therefore, various research (Anđelković, 2017, Darling-Hammond 1998, 2006; Kennedy, 1999; Milutinović, 2009; Popović \& Anđelković 2017; Vujisić-Živković 2007, Živković, 2012) confirms the lack of knowledge and practical skills which new teachers need to solve the existing school practice dilemmas. Živković (2012, 75), when discussing teachers' initial education, sets apart the existing researcher consensus that this kind of work preparation is not satisfactory, which is especially visible with secondary school teachers, so teachers, at least at the beginning of their careers, are forced to work intuitively, while Vujisić-Živković (2007, 245) notices

"that in the area of teachers' professional education, the tension between the role of researcher and practitioner has not disappeared, while pedagogues today, even more than before, have a developed awareness of the differences between these roles."

Korthagen (2001) suggested that teacher education should choose realistic approaches rather than traditional approaches and face the existing problems of changing teachers and education. For that reason, the end of the last century was marked by Competency Based Education ( $\mathrm{CBE}$ ) that implies teaching which is adaptive to the changing needs of all subjects in schools. Higher education has an obligation to care about competencies of its own students. Burke (2005), as a reason for the formation of competence based movement in education and training (CBET), singled out the idea of minimum competency for industrial/business world. It originated at the beginning of 20th Century, while around 1960, it was recognized in the field of education, especially in teacher education. These approaches are focused on learning outcomes and what the learners should learn to do.

This dichotomy has been noticed in teachers' professional education, (Anđelković, 2017), but it also exists in preparation of pedagogues for work in schools (Ledić \& al., 2013; Nikšić, 2017, Popović \& Anđelković, 2017, Staničić, 2003).

The question discussed in that paper is how much the initial education of pedagogues fulfils the postulates of school practice and prepares its candidates for the realization of practical tasks in school practice? Despite there being a half a century worth of 
research, pedagogues encounter numerous difficulties related to the specificity of this vocation. The results also point to weaknesses of professional education of pedagogues and to a lack of practical skills which should be attained during studies and through professional stimulations (Nikšić, 2017, 264). As the basis for the improvement of the quality of higher education, the four pillars of education of Delors (1996) can be taken into consideration: learning to know, learning to do, learning to live together, and learning to be, so as to develop students' competencies which help them develop more successfully but also contribute the institutions themselves. Basic education is only the beginning of development of pedagogues' competencies, it is a start of the long process of lifelong learning.

School pedagogues have been obligatory agents of change in the organization of school work from the very beginning of their engagement in schools - from the 1960s until now. Schools, as organizations whose work is based on the processes of learning and teaching, are intensively becoming different and are liable to changes ...."changes in standards and assessment, school organization and decision making, and curriculum (Ball \& Cohen, 1999, p.3). The actual changes are followed, realized, and evaluated by pedagogues, who are the bearers of many activities in schools, with the goal of further quality improvement. Authors from our area (Popović \& Anđelković 2017, Vračar \& Maksimović, 2017) note that there are no competency standards for the profession of pedagogues, although they are required. Standards are a mandatory component and a prerequisite for professional competency.

Education can never fully prepare students for the practice that awaits them (The Teaching profession in Europe: profile, trends and concerns, 2004), while rationale of authors (Zimnyaya, 2004) confirms that competences among other are the result of educational technologies, methods, organizational forms, learning environment, and as such are not constant and permanently fixed. School reality has defined different needs in relation to the required pedagogue profile. In our system of professional education, students are for the most part prepared through theoretical programs, while the crucial part is lacking, specific programs which would suggest a certain institutional affiliation during hiring. Also, there is a constant need to deliver university curricula mostly through experiential learning and involvement in practice during studies. 
It is becoming more and more apparent that school requires a practical pedagogue profile, a pedagogue who can start working right away, while professional education primarily produces a pedagogue prepared for theory. The time context changes the demands for the newly hired; to be a teacher or a pedagogue in school now is not the same as it was 10, 20 or more years ago. Educational programs are significantly inert and adjusted to the inner demands of the institutions from which they originate. Educational needs of many school subjects set new imperatives for school pedagogues whose outcomes they cannot achieve through application of theoretical knowledge, but only by developing the competencies which are required for practice. In literature (Snyder, E.P., et al. 2011, p. 71) it is noted that skills need to be developed in practice, e.g. skills for collaboration. These authors emphasize that school is a place where the lessons of human relationships are learned. Teachers, parents, and students present an unlimited variety of personalities, problems, and emotions (2011, p. 73).

These findings show that more practice should be introduced into the initial education, during which students would learn by monitoring and experiential learning while the development of their competencies would meet the set curriculum tasks. Students' and practicing pedagogues' perceptions of the influences of the acquired knowledge during studies on the concrete tasks in school are significant for the improvement of pedagogy education. The next part of the paper gives an overview of the school pedagogues' and pedagogy students' assessment of which concrete tasks set by the Regulation book on the work program for learning specialists pedagogues (2012) are encompassed by the knowledge gained during initial education.

\section{METHODOLOGY OF RESEARCH}

The goal of the research was to examine of pedagogy specialists' and students' attitudes as well as differences in opinion on the influence of initial education on the application of theoretical knowledge and development of skills for concrete tasks in school practice. The mentioned tasks are regulated by Regulation book on the work program for learning specialists - pedagogues (2012) in Serbia. The basic research question is: How much of students' 
knowledge gained through initial education is applicable to the concrete tasks in school practice, which are regulated by the law? The tasks extrapolated from the set goal are the following: 1. to determine the statistical significance of difference in opinions between school pedagogues and pedagogy students on the influence of their initial education on the development of knowledge and skills needed for completing concrete tasks in school practice; 2. to determine the statistical significance of the student subsample on the influence of their initial education on the development of knowledge and skills for completing concrete tasks in school practice, based on gender; 3 . to determine the statistical significance in the subsample of school pedagogues on the influence of their initial education on the development of knowledge and skills for completing concrete tasks in school practice, based on gender.

SAMPLE Control variable in research was the gender of students and pedagogues. Dependent variable are attitudes of pedagogy students and school pedagogues on the readiness to do the tasks which are regulated by Regulation book on the work program for learning specialists - pedagogues (2012). The research was done in May, 2015 , and the sample was appropriately formed. It encompassed 165 examinees, (77 senior students of Pedagogy at the Faculty of Philosophy in Novi Sad, Belgrade, Kosovska Mitrovica and 88 pedagogues from schools on the territory of Serbia. The structure of the examinees by gender is shown in Table 1 .

\begin{tabular}{|c|c|c|c|c|}
\hline & & \multicolumn{2}{|c|}{ GENDER } & \multirow{2}{*}{ TOTAL } \\
\hline & & $\mathrm{M}$ & $\bar{F}$ & \\
\hline \multirow{2}{*}{ STUDENTS OF PEDAGOGY } & Total & 4 & 73 & 77 \\
\hline & $\%$ & $5.2 \%$ & $94.8 \%$ & $100 \%$ \\
\hline \multirow{2}{*}{ Pedagogues } & Total & 11 & 77 & 88 \\
\hline & $\%$ & $12.5 \%$ & $87.5 \%$ & $100 \%$ \\
\hline \multirow{2}{*}{ TOTAL } & Total & 15 & 150 & 165 \\
\hline & $\%$ & $9.1 \%$ & $90.9 \%$ & $100 \%$ \\
\hline
\end{tabular}

TABLE 1: THE STUDY SAMPLE BY GENDER

From the total number of senior students, who participated in the poll, $94.8 \%$ are females while $5.2 \%$ are males. In the sample of pedagogues, $87.5 \%$ are females, while $12.5 \%$ are males. These data 
indicate a strong feminization of the profession of pedagogue. According to the obtained values $\left(?^{2}=2.65, \mathrm{df}=1, \mathrm{p}=0.103\right)$, there is no statistically significant difference regarding the gender of the examinees.

INSTRUMENT The applied instrument, designed for the requirements of this AND research, consists of an evaluation scale. The items are taken from PROCEDURES pedagogue practice, defined by Regulation book on the work program for learning specialists - pedagogues (2012). Although the Regulation book has nine areas, for the purpose of this research, they are reduced to the following five: 1 . Planning and programming of educational work (8 items); 2 . Monitoring and evaluation of educational work (7 items); 3. Working with teachers (7 items); 4. Working with children - students (4 items); 5. Cooperation with parents, director, other institutions, and keeping record (4 items). The participants were offered a five-level scale ( 1 - Yes, I completely agree, 2 - I mostly agree, 3 - No stance, 4 - I mostly disagree, 5 - I disagree). The reliability of the questionnaire was checked by reliability of the internal consistency, when the value of Cronbach's alpha coefficient was calculated (Cronbach's alpha $\alpha$ ). Since the values of Cronbach's Alpha coefficient for students is 0.94 and for pedagogues it is 0.95 , a high reliability of the instrument is confirmed. Quantitative data analysis was done through SPSS 15.0., by using the following statistical procedures. In this paper, the presented answers of examinees are calculated by arithmetic mean (M) and standard deviation (SD). The degree of connection between variables was measured by $t$ test $(t)$ and level of significance $(p)$ was obtained.

RESULTS

The obtained results are divided into five areas of school pedagogue's work and are the analysis of the two subsamples: a) pedagogy students and b) school pedagogues. One of the research aspects were students' and pedagogues' competencies for certain concrete program assignments, which are defined by Regulation book on the work program for learning specialists - pedagogues. Their answers in the category Planning and programming of educational work are shown in Table 2. 
Collection of Papers of the Faculty of Philosophy XLVII (3)/2017

\begin{tabular}{|c|c|c|c|c|c|c|}
\hline $\begin{array}{c}\text { PLANNING AND PROGRAMMING OF } \\
\text { EDUCATIONAL WORK }\end{array}$ & Group & $\mathrm{N}$ & M & SD & $\mathrm{T}$ & $\mathrm{P}$ \\
\hline \multirow{2}{*}{$\begin{array}{l}\text { MAKING SCHOOL PROGRAM AND } \\
\text { INSTITUTIONAL DEVELOPMENT PLAN }\end{array}$} & Students & 77 & 3.29 & 1.01 & \multirow[t]{2}{*}{-1.63} & \multirow[t]{2}{*}{0.10} \\
\hline & Pedagogues & 91 & 3.57 & 1.22 & & \\
\hline \multirow{2}{*}{$\begin{array}{l}\text { PARTICIPATING AND MAKING INSTITUTION'S } \\
\text { ANNUAL WORK PLAN }\end{array}$} & Students & 77 & 3.27 & 1.07 & \multirow[t]{2}{*}{-0.20} & \multirow[t]{2}{*}{0.84} \\
\hline & Pedagogues & 91 & 3.31 & 1.21 & & \\
\hline \multirow{2}{*}{$\begin{array}{l}\text { PREPARING YEARLY AND MONTHLY } \\
\text { PEDAGOGUE WORK PLANS }\end{array}$} & Students & 77 & 3.23 & 1.18 & \multirow[t]{2}{*}{2.33} & \multirow[t]{2}{*}{0.02} \\
\hline & Pedagogues & 91 & 2.80 & 1.21 & & \\
\hline \multirow{2}{*}{$\begin{array}{l}\text { DOING AND ANALYZING RESEARCH IN } \\
\text { SCHOOLS }\end{array}$} & Students & 77 & 2.51 & 1.20 & \multirow[t]{2}{*}{0.62} & \multirow[t]{2}{*}{0.54} \\
\hline & Pedagogues & 91 & 2.40 & 1.12 & & \\
\hline \multirow{2}{*}{$\begin{array}{l}\text { PARTICIPATING IN THE PREPARATION OF } \\
\text { INDIVIDUAL EDUCATION PLAN (IEP) }\end{array}$} & Students & 77 & 3.44 & 1.18 & \multirow[t]{2}{*}{-2.45} & \multirow[t]{2}{*}{0.02} \\
\hline & Pedagogues & 91 & 3.90 & 1.24 & & \\
\hline \multirow{2}{*}{ PARTICIPATING IN PROJECT WRITING } & Students & 77 & 2.55 & 1.16 & \multirow[t]{2}{*}{-3.84} & \multirow[t]{2}{*}{0.00} \\
\hline & Pedagogues & 91 & 3.27 & 1.27 & & \\
\hline \multirow{2}{*}{$\begin{array}{c}\text { HELPING TEACHERS IN MAKING } \\
\text { COMPLEMENTARY, ADDITIONAL WORK, } \\
\text { PRACTICAL LESSONS, AMBIENT LEARNING... }\end{array}$} & Students & 77 & 3.42 & 1.14 & \multirow[t]{2}{*}{3.29} & \multirow[t]{2}{*}{0.00} \\
\hline & Pedagogues & 91 & 2.84 & 1.14 & & \\
\hline \multirow{2}{*}{ FORMING CLASSES } & Students & 76 & 3.54 & 1.24 & \multirow[t]{2}{*}{2.71} & \multirow[t]{2}{*}{0.01} \\
\hline & Pedagogues & 91 & 3.02 & 1.22 & & \\
\hline
\end{tabular}

TABLE 2: ASSESSMENTS OF THE STUDENTS' AND PEDAGOGUES' COMPETENCIES FOR INDIVIDUAL PROGRAM TASKS PRESCRIBED BY THE RULEBOOK DEVELOPMENT (PLANNING AND PROGRAMMING OF EDUCATIONAL WORK)

In the area of Planning and programming of educational work there are statistically significant differences in the assessments by pedagogues and pedagogy students on several concrete tasks: Preparing yearly and monthly pedagogue work plans, participating in the preparation of Individual Education Plan (IEP); Participating in project writing, helping teachers in making complementary, additional work, practical lessons, ambient learning, and Forming classes. Based on the obtained values and significance levels pedagogy students feel more prepared for Participating in the preparation of Individual Education Plan - IEP $(\mathrm{M}=3.44, \mathrm{t}=-2.45, \mathrm{p}=$ 0.02 ) than those who already work; Participating in project writing $(\mathrm{M}=2.55, \mathrm{t}=-3.48, \mathrm{p}=0.00)$, while in other three areas there was $\mathrm{a}$ statistical significance: Preparing yearly and monthly pedagogue 
work plans $(\mathrm{M}=2.80, \mathrm{t}=2.33, \mathrm{p}=0.02)$; Helping teachers in making complementary, additional work, practical lessons, ambient learning $(\mathrm{M}=2.84, \mathrm{t}=3.29, \mathrm{p}=0.00)$; Forming classes $(\mathrm{M}=3.02$, $\mathrm{t}$ test $=-2.71$ $\mathrm{p}=0.01$ ) school pedagogues feel more prepared. Table 3 shows responses of the participants in the category Monitoring and evaluation of educational work.

\begin{tabular}{|c|c|c|c|c|c|c|}
\hline $\begin{array}{c}\text { MONITORING AND EVALUATION OF } \\
\text { EDUCATIONAL WORK }\end{array}$ & GROUP & $\mathrm{N}$ & M & SD & $\mathrm{T}$ & $P$ \\
\hline \multirow{2}{*}{$\begin{array}{c}\text { SYSTEMATIC MONITORING AND ASSESSING OF } \\
\text { EDUCATIONAL WORK, I.E. STUDENTS' } \\
\text { LEARNING PROCESS }\end{array}$} & Students & 77 & 2.71 & 1.07 & \multirow[t]{2}{*}{0.46} & \multirow[t]{2}{*}{0.64} \\
\hline & Pedagogues & 91 & 2.64 & 1.07 & & \\
\hline \multirow{2}{*}{ MONITORING OF EDUCATIONAL WORK } & Students & 77 & 2.56 & 0.94 & \multirow[t]{2}{*}{-0.22} & \multirow[t]{2}{*}{0.83} \\
\hline & Pedagogues & 91 & 2.59 & 1.11 & & \\
\hline \multirow{2}{*}{$\begin{array}{l}\text { MONITORING OF THE EFFECTS OF INNOVATIVE } \\
\text { ACTIVITIES AND PROJECTS AS WELL AS OF NEW } \\
\text { ORGANIZATIONAL FORMS OF WORK }\end{array}$} & Students & 77 & 3.19 & 1.05 & \multirow[t]{2}{*}{1.52} & \multirow[t]{2}{*}{0.13} \\
\hline & Pedagogues & 91 & 2.92 & 1.24 & & \\
\hline \multirow{2}{*}{$\begin{array}{l}\text { WORKING ON THE DEVELOPMENT AND } \\
\text { PREPARATION OF INSTRUMENTS FOR } \\
\text { ASSESSMENTS AND SELF-ASSESSMENTS OF } \\
\text { ACTIVITIES AND AREAS }\end{array}$} & Students & 76 & 3.08 & 1.07 & \multirow[t]{2}{*}{0.46} & \multirow[t]{2}{*}{0.65} \\
\hline & Pedagogues & 91 & 3.00 & 1.15 & & \\
\hline \multirow{2}{*}{$\begin{array}{l}\text { INITIALIZING AND PARTICIPATING IN } \\
\text { RESEARCH OF EDUCATION PRACTICE }\end{array}$} & Students & 77 & 2.79 & 1.08 & \multirow[t]{2}{*}{0.62} & \multirow[t]{2}{*}{0.54} \\
\hline & Pedagogues & 91 & 2.68 & 1.22 & & \\
\hline \multirow{2}{*}{$\begin{array}{l}\text { PARTICIPATING IN MONITORING REALIZATION } \\
\text { OF THE GENERAL AND SPECIAL STANDARDS }\end{array}$} & Students & 77 & 3.30 & 0.95 & \multirow[t]{2}{*}{-1.81} & \multirow[t]{2}{*}{0.07} \\
\hline & Pedagogues & 91 & 3.60 & 1.20 & & \\
\hline \multirow{2}{*}{$\begin{array}{l}\text { MONITORING OF STUDENT FAILURE AND } \\
\text { SUGGESTING OF SOLUTIONS FOR THE } \\
\text { IMPROVEMENT OF SCHOOL SUCCESS }\end{array}$} & Students & 77 & 3.03 & 1.18 & \multirow[t]{2}{*}{2.67} & \multirow[t]{2}{*}{0.01} \\
\hline & Pedagogues & 91 & 2.56 & 1.08 & & \\
\hline
\end{tabular}

TABLE 3: ASSESSMENTS OF THE STUDENTS' AND PEDAGOGUES' COMPETENCIES FOR INDIVIDUAL PROGRAM TASKS PRESCRIBED BY THE RULEBOOK DEVELOPMENT (MONITORING AND EVALUATION OF EDUCATIONAL WORK)

The only significant difference in the area of pedagogues' work and pedagogies is seen in the items: Monitoring of student failure and suggesting of solutions for the improvement of school success. Based on the obtained values $(\mathrm{M}(\mathrm{s})=3.03, \mathrm{M}(\mathrm{p})=2.56, \mathrm{t}=2.67$, $\mathrm{p}=0.01$ ) it was confirmed that the students, when it comes to this task, think that the initial education has prepared them for work 
more than practicing pedagogues. Table 4 shows the responses of students and pedagogues in the category Working with teachers.

\begin{tabular}{|c|c|c|c|c|c|c|}
\hline WORKING WITH TEACHERS & Group & $\mathrm{N}$ & $M$ & SD & $\mathrm{T}$ & $P$ \\
\hline \multirow{2}{*}{$\begin{array}{c}\text { PROVIDING HELP TO TEACHERS IN SPECIFYING } \\
\text { AND OPERATIONALIZING AIMS AND TASKS OF } \\
\text { EDUCATIONAL WORK }\end{array}$} & Students & 77 & 3.21 & 1.15 & \multirow[t]{2}{*}{4.27} & \multirow[t]{2}{*}{0.00} \\
\hline & Pedagogues & 91 & 2.46 & 1.11 & & \\
\hline \multirow{2}{*}{$\begin{array}{l}\text { PROVIDING HELP TO TEACHERS IN IMPROVING } \\
\text { THE QUALITY OF EDUCATIONAL WORK, } \\
\text { TEACHING THROUGH INNOVATION }\end{array}$} & Students & 77 & 2.88 & 1.14 & \multirow[t]{2}{*}{2.01} & \multirow[t]{2}{*}{0.05} \\
\hline & Pedagogues & 91 & 2.54 & 1.09 & & \\
\hline \multirow{2}{*}{$\begin{array}{l}\text { MOTIVATING TEACHERS FOR CONTINUOUS } \\
\text { PROFESSIONAL DEVELOPMENT AND FOR } \\
\text { MAKING PROFESSIONAL DEVELOPMENT PLANS }\end{array}$} & Students & 77 & 3.01 & 1.27 & \multirow[t]{2}{*}{-0.51} & \multirow[t]{2}{*}{0.61} \\
\hline & Pedagogues & 91 & 3.11 & 1.17 & & \\
\hline \multirow{2}{*}{$\begin{array}{l}\text { PROVIDING EXPERT ASSISTANCE TO TEACHERS } \\
\text { FOR USING VARIOUS METHODS, TECHNIQUES, } \\
\text { AND ASSESSMENT INSTRUMENTS }\end{array}$} & Students & 77 & 2.78 & 1.10 & \multirow[t]{2}{*}{1.27} & \multirow[t]{2}{*}{0.21} \\
\hline & Pedagogues & 91 & 2.56 & 1.13 & & \\
\hline \multirow{2}{*}{$\begin{array}{c}\text { PROVIDING SUPPORT FOR TEACHERS IN } \\
\text { WORKING WITH STUDENTS WHO NEED } \\
\text { ADDITIONAL SUPPORT }\end{array}$} & Students & 77 & 2.95 & 1.22 & \multirow[t]{2}{*}{-0.83} & \multirow[t]{2}{*}{0.41} \\
\hline & Pedagogues & 91 & 3.11 & 1.29 & & \\
\hline \multirow{2}{*}{$\begin{array}{l}\text { PROVIDING HELP TO TEACHERS IN } \\
\text { REALIZATION OF EXPERIMENTAL AND } \\
\text { DEMONSTRATIVE ACTIVITIES }\end{array}$} & Students & 77 & 3.43 & 1.30 & \multirow[t]{2}{*}{0.70} & \multirow[t]{2}{*}{0.48} \\
\hline & Pedagogues & 91 & 3.29 & 1.32 & & \\
\hline \multirow{2}{*}{$\begin{array}{l}\text { PROVIDING ASSISTANCE TO TEACHERS IN } \\
\text { PREPARING TEACHING LICENSE EXAM }\end{array}$} & Students & 76 & 3.86 & 1.13 & \multirow[t]{2}{*}{2.59} & \multirow[t]{2}{*}{0.01} \\
\hline & Pedagogues & 91 & 3.34 & 1.39 & & \\
\hline
\end{tabular}

TABLE 4: ASSESSMENTS OF THE STUDENTS' AND PEDAGOGUES' COMPETENCIES FOR INDIVIDUAL PROGRAM TASKS PRESCRIBED BY THE RULEBOOK DEVELOPMENT (WORKING WITH TEACHERS)

There are statistically significant differences between the assessments of working pedagogues and pedagogy students in three items: Providing help to teachers in specifying and operationalizing aims and tasks of educational work $(\mathrm{M}=2.46, \mathrm{t}=4.27 \mathrm{p}=0.00)$; Providing help to teachers in improving the quality of educational work, teaching through innovation $(\mathrm{M}=2.54, \mathrm{t}=2.01 \mathrm{p}=0.05)$; Providing assistance to teachers in preparing teaching license exam $(\mathrm{M}=3.02, \mathrm{t}=2.59 \mathrm{p}=0.01)$. School pedagogues, based on the values, think that the initial education has prepared them significantly more for work in these tasks. Table 5 shows assessments of the respondents in the category - Working with children students. 
University Education of Pedagogues Meeting Demands of School Practice

\begin{tabular}{|c|c|c|c|c|c|c|}
\hline WORKING WITH CHILDREN - STUDENTS & GROUP & $\mathrm{N}$ & M & SD & $\mathrm{T}$ & $P$ \\
\hline \multirow{2}{*}{$\begin{array}{l}\text { MONITORING CHILDREN'S DEVELOPMENT AND } \\
\text { ADVANCEMENT }\end{array}$} & Students & 76 & 2.75 & 1.21 & \multirow[t]{2}{*}{2.16} & \multirow[t]{2}{*}{0.03} \\
\hline & Pedagogues & 91 & 2.38 & 0.97 & & \\
\hline \multirow{2}{*}{$\begin{array}{l}\text { ADVISORY WORK WITH NEW STUDENTS, } \\
\text { STUDENTS WHO FAILED A CLASS OR CAME } \\
\text { FROM OTHER SCHOOLS }\end{array}$} & Students & 76 & 3.04 & 1.19 & \multirow[t]{2}{*}{2.37} & \multirow[t]{2}{*}{0.02} \\
\hline & Pedagogues & 91 & 2.62 & 1.11 & & \\
\hline \multirow{2}{*}{$\begin{array}{l}\text { PROMOTING AND SUGGESTING MEASURES, } \\
\text { PARTICIPATING IN ACTIVITIES SO AS TO REDUCE } \\
\text { VIOLENCE AND INCREASE TOLERANCE... }\end{array}$} & Students & 76 & 2.93 & 1.09 & \multirow[t]{2}{*}{-1.33} & \multirow[t]{2}{*}{0.19} \\
\hline & Pedagogues & 91 & 3.19 & 1.32 & & \\
\hline \multirow{2}{*}{$\begin{array}{c}\text { PARTICIPATION IN MAKING PEDAGOGICAL } \\
\text { STUDENTS' PROFILE FOR THOSE WHO NEED } \\
\text { ADDITIONAL SUPPORT }\end{array}$} & Students & 76 & 3.08 & 1.15 & \multirow[t]{2}{*}{-2.27} & \multirow[t]{2}{*}{0.02} \\
\hline & Pedagogues & 91 & 3.51 & 1.25 & & \\
\hline
\end{tabular}

TABLE 5: ASSESSMENTS OF THE STUDENTS' AND PEDAGOGUES' COMPETENCIES FOR INDIVIDUAL PROGRAM TASKS PRESCRIBED BY THE RULEBOOK DEVELOPMENT (WORKING WITH CHILDREN - STUDENTS)

Statistically significant differences have been confirmed in the following three items: Monitoring children's development and advancement $(\mathrm{M}(\mathrm{s})=2.75, \mathrm{M}(\mathrm{p})=2.38, \mathrm{t}=2.16, \mathrm{p}=0.03)$; Advisory work with new students or students who failed a class or came from other schools ( $\mathrm{M}(\mathrm{s})=3.04, \mathrm{M}(\mathrm{p})=2.62, \mathrm{t}=2.37, \mathrm{p}=0.02)$; Participation in making pedagogical students' profile for those who need additional support $(\mathrm{M}(\mathrm{s})=3.08, \mathrm{M}(\mathrm{p})=3.51, \mathrm{t}=-2.27, \mathrm{p}=0.02)$. The obtained statistical values indicate that for the first two tasks pedagogues feel more prepared for work in school practice than students. For the third item with statistical significance students see themselves as more prepared. Table 6 shows the responses in several categories: Cooperation with parents, director, other institutions, and keeping record.

\begin{tabular}{|c|c|c|c|c|c|c|}
\hline $\begin{array}{l}\text { COOPERATION WITH PARENTS, DIRECTOR, } \\
\text { OTHER INSTITUTIONS, AND KEEPING RECORD }\end{array}$ & GROUP & $\mathrm{N}$ & M & SD & $\mathrm{T}$ & $\mathrm{P}$ \\
\hline PREPARING AND REALIZATION OF PARENT & Students & 77 & 3.17 & 1.28 & \multirow[t]{2}{*}{0.58} & \multirow[t]{2}{*}{0.56} \\
\hline $\begin{array}{c}\text { MEETINGS, FORUMS, WORKSHOPS WITH EXPERT } \\
\text { THEMATIC }\end{array}$ & $\begin{array}{l}\text { Peda- } \\
\text { gogues }\end{array}$ & 91 & 3.05 & 1.24 & & \\
\hline
\end{tabular}

TABLE 6: ASSESSMENTS OF THE STUDENTS' AND PEDAGOGUES' COMPETENCIES FOR INDIVIDUAL PROGRAM TASKS PRESCRIBED BY THE RULEBOOK DEVELOPMENT (COOPERATION WITH PARENTS, DIRECTOR, OTHER INSTITUTIONS, AND KEEPING RECORD) 
Collection of Papers of the Faculty of Philosophy XLVII (3)/2017

\begin{tabular}{|c|c|c|c|c|c|c|}
\hline \multirow{2}{*}{$\begin{array}{l}\text { COOPERATION WITH THE PRINCIPAL AND } \\
\text { EXPERT ASSOCIATES ON JOINT PLANNING OF } \\
\text { ACTIVITIES... }\end{array}$} & Students & 77 & 3.17 & 1.21 & \multirow[t]{2}{*}{-0.10} & \multirow[t]{2}{*}{0.92} \\
\hline & $\begin{array}{l}\text { Peda- } \\
\text { gogues }\end{array}$ & 91 & 3.19 & 1.19 & & \\
\hline \multirow[b]{2}{*}{$\begin{array}{l}\text { SUGGESTING MEASURES FOR THE } \\
\text { IMPROVEMENT OF EXPERT BODIES }\end{array}$} & Students & 76 & 3.41 & 1.12 & \multirow[t]{2}{*}{1.78} & \multirow[t]{2}{*}{0.08} \\
\hline & $\begin{array}{l}\text { Peda- } \\
\text { gogues }\end{array}$ & 90 & 3.10 & 1.10 & & \\
\hline \multirow{2}{*}{$\begin{array}{l}\text { DESIGNING OF PROGRAM ACTIVITIES FOR THE } \\
\text { IMPROVEMENT OF PARTNER RELATIONSHIPS } \\
\text { AMONG FAMILIES, INSTITUTION, AND LOCAL }\end{array}$} & Students & 75 & 3.07 & 1.17 & \multirow[t]{2}{*}{0.24} & \multirow[t]{2}{*}{0.81} \\
\hline & $\begin{array}{l}\text { Peda- } \\
\text { gogues }\end{array}$ & 88 & 3.02 & 1.20 & & \\
\hline
\end{tabular}

TABLE 6: ASSESSMENTS OF THE STUDENTS' AND PEDAGOGUES' COMPETENCIES FOR INDIVIDUAL PROGRAM TASKS PRESCRIBED BY THE RULEBOOK DEVELOPMENT (COOPERATION WITH PARENTS, DIRECTOR, OTHER INSTITUTIONS, AND KEEPING RECORD)

In the category Cooperation with parents, director, other institutions, and keeping record, no statistically significant differences between school pedagogues and pedagogy students have been confirmed.

Within the first research task, our intention was to determine whether there exists statistically relevant difference in students' opinions in relation to gender. When compared to previous table, we have separated items in which there was statistical significance. Results are shown in Table 7.

\begin{tabular}{|c|c|c|c|c|c|c|}
\hline SCHOOL PEDAGOGUE'S PROGRAM TASKS & GENDER & $\mathrm{N}$ & $M$ & SD & $\mathrm{T}$ & $P$ \\
\hline \multirow{2}{*}{$\begin{array}{c}\text { PARTICIPATING AND MAKING INSTITUTION'S } \\
\text { ANNUAL WORK PLAN }\end{array}$} & M & 4 & 2 & 0 & \multirow[t]{2}{*}{-2.524} & \multirow[t]{2}{*}{.014} \\
\hline & F & 73 & 3.34 & 1.06 & & \\
\hline \multirow{2}{*}{$\begin{array}{c}\text { PREPARING YEARLY AND MONTHLY PEDAGOGUE } \\
\text { WORK PLANS }\end{array}$} & $\mathrm{M}$ & 4 & 2 & 0 & \multirow[t]{2}{*}{-2.202} & \multirow[t]{2}{*}{.031} \\
\hline & F & 73 & 3.3 & 1.17 & & \\
\hline \multirow{2}{*}{ FORMING CLASSES } & $\mathrm{M}$ & 4 & 1.5 & 0.58 & \multirow[t]{2}{*}{-3.654} & \multirow[t]{2}{*}{.000} \\
\hline & $\mathrm{F}$ & 72 & 3.65 & 1.16 & & \\
\hline \multirow{2}{*}{ MONITORING OF EDUCATIONAL WORK } & $\mathrm{M}$ & 4 & 1.5 & 0.58 & \multirow[t]{2}{*}{-2.386} & \multirow[t]{2}{*}{.020} \\
\hline & F & 73 & 2.62 & 0.92 & & \\
\hline \multirow{2}{*}{$\begin{array}{l}\text { PROVIDING SUPPORT FOR TEACHERS IN WORKING } \\
\text { WITH STUDENTS WHO NEED ADDITIONAL SUPPORT }\end{array}$} & M & 4 & 1.75 & 0.5 & \multirow[t]{2}{*}{-2.053} & \multirow[t]{2}{*}{.044} \\
\hline & $\bar{F}$ & 73 & 3.01 & 1.22 & & \\
\hline
\end{tabular}

TABLE 7: THE ASSESSMENTS OF STUDENTS' COMPETENCE DEVELOPMENT FOR INDIVIDUAL PROGRAM TASKS DEFINED BY THE RULEBOOK (STATISTICALLY RELEVANT BY GENDER) 
It is interesting, that even though the sample encompassed a small percentage of males, in some items they see their readiness for school practice in a more positive way. Male students are mostly prepared for Participating and making institution's annual work plan $(M=2)$ in relation to female students $(M=3.34)$, as well as Preparing yearly and monthly pedagogue work plans $(t=-2,202)$, Forming classes $(t=-3.654)$, Monitoring of educational work $(t=-2.386)$, as well as Providing support for teachers in working with students who need additional support $(t=-2.053)$. The stated examples point to rethinking of including peer education as a learning system during practice for certain courses, which would make male students an important resource for strengthening female student competencies. The given example can be applied to all situations in which a certain group of students stands out from the rest, and in that way it can contribute to realizing outcomes of certain courses.

In the subsample of school pedagogues, when it comes to gender, not one item shows statistical significance, which confirms that there are no differences in assessments between male and female pedagogues of the influence of their initial education on performing certain practical tasks in schools.

\section{DISCUSSION}

The obtained research results show that there are statistically significant differences in assessments of preparation for professional practice between students. We can safely presume, based on the result, that school pedagogues have been positively influenced by the initial education, while pedagogy students diminish the influence of and contact with school practice. The mean values (M) with both subsamples may set apart tasks which have lowest assessments, those for which the practitioners and students deem themselves less fit.

In the subsample of pedagogues these are the following items: Making school program and institution's development plan $(\mathrm{M}=3.57)$; Participating in the preparation of Individual Education Plan (IEP) $(\mathrm{M}=3.90)$; Participating in project writing $(\mathrm{M}=3.27)$; Participating in monitoring and realization of the general and special standards $(M=3.60)$; Providing help to teachers in realization of experimental and demonstrative activities $(\mathrm{M}=3.29)$; 
Participation in making pedagogical students' profile for those who need additional support $(\mathrm{M}=3.51)$.

In the subsample of students these are the following items: Participating in the preparation of Individual Education Plan (IEP) $(\mathrm{M}=3.44)$; Helping teachers in making complementary, additional work, practical lessons, ambient learning $(\mathrm{M}=3.42)$; Forming classes $(M=3.54)$; Providing help to teachers in realization of experimental and demonstrative activities $(M=3.43)$; Providing assistance to teachers in preparing teaching license exam $(\mathrm{M}=$ 3.86); Suggesting measures for the improvement of expert bodies $(\mathrm{M}=3.41)$.

Also, the choice of program tasks within the categories in which they have been prepared for shows that students are more competent for research and perceiving real state, than for improving the quality of overall school work, and in that sense, of education itself. It is also important to stress the fact that the responses show lower preparation of students for tasks which are included in Regulation book on the work program for learning specialists - pedagogues in 2012., i.e., tasks which were not present in the study program at that time, and which refer to self-evaluation, school program, development planning, educational standards, individual education plan, and the like. The stated results point to a necessity for redefining study programs in Pedagogy, as well as increased involvement of pedagogical practice in school, so that students can learn through experience and can be adequately prepared for their professional practice. The attained results illustrate the influence of initial education on the development of concrete pedagogue competencies, needed in school practice, as well as possible ways to change the study programs.

CONCLUSION Based on the obtained answers from these two subsamples, we can conclude that the current education of pedagogues has been improved by more contemporary demands which are reflected in the need for writing and involvement in projects; therefore, students, in comparison to school pedagogues, feel more prepared for such tasks. They, in their assessment, based on statistical values, better assess their preparedness to work with teachers. The contribution of this paper is in the perception of the possibilities for betterment of school pedagogue practice and professional education, through analysis of the results obtained through deep reflection and the experience of the respondents. The limitations of 
the study are reflected in the fact that the students from all university centers in Serbia are not encompassed, while school pedagogues are widely dispersed, so it was difficult to include more participants. There are several ways to improve and enhance pedagogues' competencies for work in schools: 1. Curricula for pedagogue education need to be more focused on practice and to include practical tasks in schools; 2 . Students need more time during which they would be involved in direct work, with all subjects, and be included in the reality of the school practice; 3 . Develop the mentorship program in which pedagogues would "handle" induction of new pedagogues into the school system. 4. Develop systematic connections between faculties which educate pedagogues with the real-world practice.

Apart from changes in the initial education, the pedagogues have to independently meet the demands set by the society, active school context, colleagues, parents, and children. Finally, one might say that self-development and self-improvement have become a professional necessity, which paves the way for a reflective search in the areas of school practice. Although the list of pedagogue competencies, as afore mentioned, can never be completed, there still remains the possibility that there should exist standards for this profession so as to further the practice. Ultimately, even pedagogue education can use suggestions related to teacher education "solution must lie in large part with strong, universal teacher education" (Darling Hammond, 2006 5).

\footnotetext{
REFERENCES Анђелковић, А. (2017). Професионални развој у образовању-йеgаїошки кон-

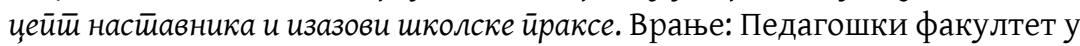
Врању.

Вујисић-Живковић, Н. (2007). Педагошка истраживања и образовање на-

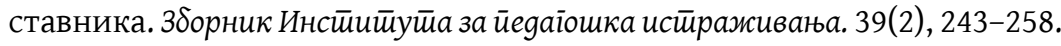

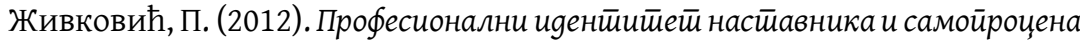

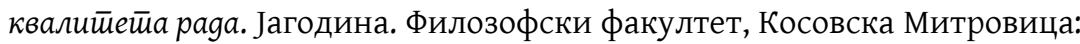
Каирос.

Burke, J. (2005). Competency based education and training: Background and Origins In: J. Burke (Ed.), Competency Based Education and Training. London, New York and Philadelphia: The Flamer Press.

Darling-Hammond, L. (1998). Teacher Learning That Supports Student Learning. Educational Leadership, 55, 5, 6-11.
} 
Darling-Hammond, L. (2006). Powerful teacher education: lessons from exemplary programs. San Francisco: Jossey-Bass.

Delors, J. \& al. (1996). Learning: The treasure within. Paris: UNESCO.

Department of Education (2015). Competency framework for school psychologists. Western Australia.

Dewey, J. (2001). Democracy and Education. The Pennsylvania State University. Retrieved from: http://library.um.ac.id/images/stories/ebooks/Juni10/democracy\%20and\%20education\%20-\%20john\%20dewey.pdf.

Kennedy, M. (1999). The Role of Preservice Teacher Education. In: L. Darling-Hammond \& G. Sykes (Eds.), Teaching as the Learning profession: handbook of policy and practice (54-85). San-Francisco: Jossey-Bass.

Korthagen, F. (2001). Linking practice and theory: the pedagogy of realistic teacher education. Institute of Education Utrecht University The Netherlands. Paper presented at the Annual Meeting of the American Educational Research Association, Seattle, April 2001. Retrieved from: http://www.dl.icdst.org/pdfs/ files1/8def2fb45db95cab3719a793f85a605e.pdf.

Ledić, J., Stančić, S., \& Turk, M. (2013). Kompetencije školskih pedagoga. Rijeka: Filozofski fakultet u Rijeci.

Lortie, S. (1975). Schoolteacher: a sociological study. Chicago: University of Chicago Press.

Makulova, A., Alimzhanova, G., Bekturganova, Z., Umirzakova, Z., Makulova, L., \& Karymbayeva, K. (2015). Theory and practice of competency-based approach in education. International Education Studies, 8(8), 183-192. doi:10.5539/ies.v8n8p183.

Milutinović J. (2009). Teorija, obrazovna praksa i profesionalni razvoj nastavnika. Zbornik radova Evropske dimenzije promena obrazovnog sistema u Srbiji, 5, (37-53). Novi Sad: Filozofski fakultet u Novom Sadu.

Nikšić, E. (2017). Savjetodavni rad školskog pedagoga. U: M. Turk (Ur.), Suvremeni izazovi u radu (školskog) pedagoga (252-268). Rijeka: Filozofski fakultet u Rijeci Sveučilište u Rijeci.

Popović. D., Anđelković A. (2017). Školski pedagozi o područjima rada pedagoga - praksa, teorija i zakonska regulativa. U: M. Turk (Ur.), Suvremeni izazovi u radu (školskog) pedagoga (292-308). Rijeka: Filozofski fakultet u Rijeci Sveučilište u Rijeci.

Pravilnik o programu svih oblika rada stručnih saradnika (2012) Beograd: Službeni Glasnik RS, br 72/09 i 52/11).

Shulman, L. S. (1986). Those who understand: Knowledge growth in teaching. Educational Researcher, 15(2), 4-31. 
Shulman, L. S. (1987). Knowledge and teaching: Foundations of the new reform. Harvard Educational Review, 57(1), 1-22.

Snyder, E.P., Quick, K. \& DeMatteo, F. (2011). Consulting with families, schools, and communities. In: Lionetti, T. M., Snyder, E. P. \& Christner, R. W. (Eds.), A practical guide to building professional competencies in school psychology (pp. 69-81). New York, NY, Springer Science.

Staničić, S. (2003). Veza ravnatelja i pedagoga u radu i kompetencijama. Školski priručnik 2003./2004., 183-188.

Teaching Profession in Europe: Profile, Trends and Concerns: General Lower Secondary Education. Keeping teaching attractive for the 21st century. (2004) Eurydice, European Unit.

Vračar, M., Maksimović, A. (2017). Perspektiva pedagoga; kompetencije potrebne za uspješno profesionalno djelovanje. U: M. Turk (Ur.), Suvremeni izazovi u radu (školskog) pedagoga (214-235). Rijeka: Filozofski fakultet u Rijeci Sveučilište u Rijeci.

Zeichner, K., Tabachnik, B. R. (1981). Are the effects of university teacher education washed out by school experiences? Journal of Teacher Education, 32, 7-11.

Zimnyaya, I. A. (2004). Key competencies as effectively-targeted base of competency-based approach in education. Moscow: Research Center of the problems of the quality of specialist's training.

АЛЕКСАНДРА К. АНЂЕЛКОВИЋ

УНИВЕРЗИТЕТ У НИШУ

ПЕДАГОШКИ ФАКУЛТЕТ - ВРАњЕ

ДАЛИБОРКА Р. ПОПОВИЋ

УНИВЕРЗИТЕТ У КРАГУЈЕВЦУ

ПРИРОДНО-МАТЕМАТИЧКИ ФАКУЛТЕТ - КРАГУЈЕВАЦ

РЕЗИМЕ

УНИВЕРЗИТЕТСКО ОБРАЗОВАҢЕ ПЕДАГОГА

У СУСРЕТ ЗАХТЕВИМА ШКОЛСКЕ ПРАКСЕ

Пред универзитетско образовање постављају се нови захтеви за другачијим моделима рада који ће успешније припремити студенте за изазове друштва, квалитетнију укљученост у рад у школској пракси и константну персоналну адаптабилност. Квалитет образовања будућих кандидата потребно је пратити кроз образовне потребе школске праксе те универзитетски модели поучавања треба да се ослањају на снаге и слабости опажене у 
пракси, као и на законске смернице које регулишу оквире деловања запослених педагога у школи.

Теоријско полазиште истраживања представљају радови и истраживачки резултати чији је фокус усмерен на припрему кандидата за рад у школама. Како је наставничко образовање старије од образовања педагога, дотакнута су искуства и налази из овог поља. Иначе, питање које прожима читав рад јесте: колико иницијално образовање педагога испуњава захтеве школске праксе у смислу припреме кандидата за реализацију прописаних задатака у школској пракси? Као основа за одговор на постављено истраживачко питање искоришћен је Правилник о програму свих облика рада стручних сарадника (2012), којим су дефинисани конкретни задаци школских педагога. Поменути задаци дефинисани су као истраживачки ајтеми, чије су процене о припремљености кроз универзитетско образовање дали студенти педагогије и школски педагози ( $\mathrm{N}=165)$.

Школски педагози представљају неизоставне агенсе промена у организацији рада школе. Школе, као организације чији је рад заснован на процесима учења и поучавања, интензивно се мењају и подлежу променама. Иако образовање никада не може у потпуности припремити студенте за предстојећу праксу, обавеза педагога јесте да као носиоци бројних активности у школи прате, реализују и евалуирају целокупну васпитно-образовну делатност. Школска реалност издефинисала је нове потребе у односу на актуелан профил запослених педагога. У нашем систему професионалног образовања студенти се припремају највећим делом кроз теоријске програме, док значајно изостаје круцијални део, а то су специфични програми који би наговестили извесну институционалну припадност кандидата, приликом запослења.

Истраживачки резултати указују на постојеће разлике школских педагога и студената педагогије о припремљености за конкретне прописане задатке. Студенти педагогије сеঠе виде као значајније припремљене за писање пројеката у односу на запослене педагоге. Добијени налаз може указати на то да је универзитетско образовање значајније испунило овај захтев него раниje. У одговорима школских педагога наилази се на одговоре који представљају дубоке рефлексије, условљене праксом, што је чињеница која показује њен снажан утицај на педагоге. Налази показују да у иницијално образовање треба увести више праксе, у којој би студенти учили посматрањем и искуственим учењем, 
што би условило да развијање њихових компетенција иде у сусрет предвиђеним програмским задацима. Према контролној варијабли пол, код подузорка педагога нису пронађене статистички значајне разлике, док су у подузорку педагога статистички значајне разлике добијене код четири ајтема: припрема и учешће у изради годишњег плана рада, припрема годишњих и месечних планова рада педагога, формирање одељења и праћење образовног рада. Овај податак показује да студенти педагози себе перципирају као боље припремљене у односу на студенткиње.

Поред промена у иницијалном образовању педагози морају самостално испуњавати захтеве које отварају изазови друштва, актуелни захтеви школског контекста, потребе колега, родитеља и деце. На крају, може се рећи да су саморазвој и самоусавршавање постали професионална неминовност, којом самостално трасирају пут рефлексивног трагања у областима потребним за рад у школској пракси. Иако листа компетенција педагога, као што је већ поменуто никада не може ठити заувек завршена, остаје могућност да је исту потребно сачинити и дефинисати стандарде професије ради унапређивања праксе.

КљУчнЕ РЕчи: универзитетско образовање, школа, студенти педагогије, школски педагози, Правилник о програму свих облика рада стручних сарадника.

Овај чланак је објављен и дистрибуира се под лиценцом Creative Commons Ауторство-Некомерцијално Међународна 4.0 (CC BY-NC 4.0 |

https://creativecommons.org/licenses/by-nc/4.0/).

This paper is published and distributed under the terms and conditions of the Creative Commons Attribution-NonCommercial International 4.0 licence (CC BY-NC 4.0 | https://creativecommons.org/licenses/by-nc/4.0/). 